
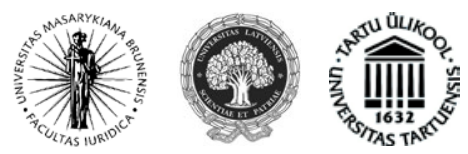

\title{
THE BEST INTERESTS OF THE CHILD ALWAYS COME FIRST: THE BRUSSELS II BIS REGULATION AND THE EUROPEAN COURT OF JUSTICE
}

\author{
Koen Lenaerts* \\ Vice-President of the Court of \\ Justice of the European Union \\ L-2925 Luxembourg \\ Telephone: (+352) 43031 \\ E-mail: Koen.Lenaerts@curia.europa.eu
}

Received on 16 September 2013; accepted on 27 December 2013.

doi:10.13165/JUR-13-20-4-02

In a 'Hollywood-like' story tale, a free mover would find professional success in the host Member State. There he or she would also find true love, get married and have children of dual nationality. In other words, he or she would be living the 'European dream' happily ever after. However, as almost all European motion pictures demonstrate, not all stories have a happy ending. Unfortunately, marriages come to an end and families break up. In a cross-border context, this often means that either the father or the mother goes back to his or her home Member State where he or she will receive the support of his or her family and friends to start over. If children are involved and one of the parents is unhappy with the ruling of the court of the host Member State, the father or the mother, upon return to his or her own Member State, may decide to start proceedings before the courts thereof, hoping that national solidarity will convince the judge to rule in his or her favour.

\footnotetext{
* All opinions expressed herein are strictly personal to the author.
} 
In order to avoid parallel litigation in both the home and the host Member State that could give rise to contradictory rulings, it is important to determine the national court which enjoys jurisdiction in matrimonial matters as well as in matters of parental responsibility, notably in cases of child abduction. This is the objective pursued by Regulation No 2201/2003 ${ }^{1}$, most commonly known as ‘the Brussels II bis Regulation'. In relation to divorce, legal separation or marriage annulment, that Regulation only applies to the dissolution of marriage ties. It does not deal with issues, such as the grounds for divorce, property consequences of the marriage or any other ancillary measures ${ }^{2}$.

Unlike its predecessor ${ }^{3}$, the Brussels II bis Regulation contains conflict-ofjurisdiction rules on matters of parental responsibility that apply to all children including those of non-married couples ${ }^{4}-$ who are habitually resident in one of the Member States of the Union at the time the court is seised ${ }^{5}$. To date, the case-law of the European Court of Justice (the ECJ) has primarily focused on the provisions of the Brussels II bis Regulation that lay down conflict-of-jurisdiction rules on matters of parental responsibility ${ }^{6}$. Moreover, those cases have mostly been dealt with under either the accelerated preliminary reference procedure or the urgent preliminary reference procedure. The ECJ has reasoned that for cases involving a child's right of custody time is of the essence. It has consistently recognised 'the urgency of ruling in cases of child removal in particular where the separation of a child from the parent to whom [...] custody had previously been awarded, even if only provisionally, would be likely to bring about a deterioration of their relationship, or harm that relationship, and to cause psychological damage.'7

1 See Council Regulation (EC) No 2201/2003 of 27 November 2003 concerning jurisdiction and the recognition and enforcement of judgments in matrimonial matters and the matters of parental responsibility, repealing Regulation (EC) No 1347/2000, OJ [2003] L 338/1.

2 See Recital 8 of the Brussels II bis Regulation. See generally, Ní Shúilleabháin, M. Cross-border Divorce Law: Brussels II bis. Oxford: OUP, 2011.

3 The Brussels II bis Regulation repeals Regulation No 1347/2000, which had a more limited scope. See Council Regulation (EC) No 1347/2000 of 29 May 2000 on jurisdiction and the recognition and enforcement of judgments in matrimonial matters and in matters of parental responsibility for children of both spouses, OJ [2000] L 160/19.

4 See Recital 5 of the Brussels II bis Regulation, which states that '[i]n order to ensure equality for all children, this Regulation covers all decisions on parental responsibility, including measures for the protection of the child, independently of any link with a matrimonial proceeding'.

5 See Article 8(1) of the Brussels II bis Regulation.

6 However, there are a few cases where the ECJ was called upon to interpret the conflict-of-jurisdiction rules on matrimonial matters. See e.g. Case C-68/07 Sundelind Lopez [2007] ECR I-10403, and Case C-168/08 Hadadi [2009] ECR I-6871.

7 See e.g. Case C-491/10 PPU Aguirre Zarraga [2010] ECR I-14247, para. 39. For an overview of the application of the urgent preliminary reference procedure, see e.g. Naômé, C. La procédure accélérée et la procédure préjudicielle d'urgence devant la Cour de justice des Communautés européennes. Journal de droit européen. 2009: 237-247; Chevalier, B. Les nouveaux développements de la procédure préjudicielle dans le domaine de l'espace judiciaire européen: la procédure préjudicielle d'urgence et les réformes principales prévues par le traité de Lisbonne. ERA Forum. 2009, 8: 591-607; Barnard, C. The PPU: Is It Worth the Candle? An Early Assessment. European Law Review. 2009, 34: 281-297; Rosas, A. Justice in Haste, Justice Denied? The European Court of Justice and the Area of Freedom, Security and Justice. Cambridge Yearbook of European Legal Studies. 2008-2009, 11: 1-13, and Lenaerts, K. The 
In interpreting the abovementioned provisions, the ECJ must take into account the following guiding principles. First, the Brussels II bis Regulation must be interpreted in such a way as to facilitate the free movement of judgments. Indeed, for the establishment of a genuine judicial area in family matters, the Brussels II bis Regulation must enhance the mutual trust between national courts. Second, as an EU measure containing conflict-of-jurisdiction rules, the Brussels II bis Regulation must be interpreted in light of the principle of legal certainty. This means that a 'balancedapproach' that favours a case-by-case solution, which is difficult to predict, must be, if possible, avoided. Indeed, in the realm of private international law, a clear-cut rule is often preferred to balancing. Third, there are multilateral Conventions containing rules on jurisdiction for decisions on custody to which Member States are parties and which predate the Brussels II bis Regulation, in particular the 1980 Hague Convention on the Civil Aspects of International Child Abduction (the 1980 Hague Convention) ${ }^{9}$. The ECJ will thus be called upon to clarify the relationship between the Brussels II bis Regulation and the abovementioned Conventions. It is true that for matters falling within its scope, the Brussels II bis Regulation takes precedence over those multilateral Conventions ${ }^{10}$. However, those Conventions may still be taken into consideration for the purposes of understanding the legislative history of the Brussels II bis Regulation. In the same way, concepts that are found in both the latter Regulation and those multilateral Conventions should be interpreted in a uniform fashion, so as to guarantee that they are 'consistently demarcated from each other" ${ }^{\prime 1}$. Needless to say, if drawing inspiration from those Conventions is incompatible with the objectives pursued by the Union, then the ECJ will have no choice but to take a different approach ${ }^{12}$. Last, but not least, as happens

Contribution of the European Court of Justice to the Area of Freedom, Security and Justice. International \& Comparative Law Quarterly. 2010, 59: 255-301.

8 See e.g. Recital 21 of the Brussels II bis Regulation, which states that ' $[t]$ he recognition and enforcement of judgments given in a Member State should be based on the principle of mutual trust and the grounds for non-recognition should be kept to the minimum required'. See also Cases C-195/08 PPU Rinau [2008] ECR I-5271, para. 50 and Aguirre Zarraga, [2010] ECR I-14247, para. 70. See Mitsilegas, V. The Limits of Mutual Trust in Europe's Area of Freedom, Security and Justice: From Automatic Inter-State Cooperation to the Slow Emergence of the Individual. Yearbook of European Law. 2012, 31: 319-372, 353.

9 The 1980 Hague Convention entered into force on 1 December, 1983.

10 See Article 60 of the Brussels II bis Regulation. In addition to the 1980 Hague Convention, Article 60 also mentions the Hague Convention of 5 October 1961 concerning the Powers of Authorities and the Law Applicable in respect of the Protection of Minors; the Luxembourg Convention of 8 September 1967 on the Recognition of Decisions Relating to the Validity of Marriages; the Hague Convention of 1 June 1970 on the Recognition of Divorces and Legal Separations; the European Convention of 20 May 1980 on Recognition and Enforcement of Decisions concerning Custody of Children and on Restoration of Custody of Children.

11 See the Opinion of AG Kokott in Case C-523/07 A [2009] ECR I-2805, paras. 22 and 23.

12 For example, whilst in the EU legal order, the principle of 'mutual trust' entails that the courts of the Member State of enforcement must defer to the determinations made by the courts of the Member State of origin, it is often the other way around for multilateral Conventions: it is for the courts of the Contracting State of origin to defer to the determinations made by the courts of the Contracting State of enforcement as to the 'best interests of the child'. Unlike multilateral Conventions, the EU law 'principle of mutual trust' operates hand-in-hand with the principle of free movement of judgments. 
with all instruments of secondary EU legislation ${ }^{13}$, the provisions of the Brussels II bis Regulation can never be interpreted in a way that is contrary to primary EU law. Hence, that Regulation must be interpreted in compliance with the fundamental rights of the child concerned, notably with Articles 7 and 24 of the Charter of Fundamental Rights of the European Union (the Charter) ${ }^{14}$.

The purpose of this contribution is thus to explore how the ECJ - in dialogue with national courts - has struck the balance among those four guiding principles of interpretation. To this effect, it supports the contention that the ECJ does not give absolute priority to the mobility of judgments over the protection of fundamental rights ${ }^{15}$. On the contrary, as the case-law clearly reveals, the ECJ will never interpret the Brussels II bis Regulation against 'the best interests of the child' 16 .

\section{The concept of habitual residence}

Article 8(1) of the Brussels II bis Regulation grants general jurisdiction in matters of parental responsibility to the courts of the Member State, in which a child 'is habitually resident $[. .$.$] at the time the court is seised' { }^{\prime 17}$. If a child's habitual residence cannot be established, and Article 12 does not apply ${ }^{18}$, the Brussels II bis Regulation states that the courts of the Member State where the child is present are to have jurisdiction ${ }^{19}$.

13 See Case C-101/01 Lindqvist [2003] ECR I-12971, para. 87, and Case C-305/05 Ordre des barreaux francophones et germanophone and Others [2007] ECR I-5305, para. 28 (holding that 'the Member States must not only interpret their national law in a manner consistent with [EU] law but also make sure they do not rely on an interpretation of an instrument of secondary legislation which would be in conflict with the fundamental rights protected by the [EU] legal order or with the other general principles of [EU] law').

14 [2012] OJ C 326/02. See also Recital 33 of the Brussels II bis Regulation.

15 In this regard, some scholars have argued that the ECJ and the European Court of Human Rights have taken opposite views on child abduction cases. Whilst the former places too much emphasis on the free movement of judgments, the latter interprets Article 8 of the ECHR in such a way as to prevent the 1980 Hague Convention from operating as a deterrent against child abduction. See, in this regard, Walker, L.; Beaumont, P. Shifting the Balance Achieved by the Abduction Convention: The Contrasting Approaches of the European Court of Human Rights and the European Court of Justice. Journal of Private International Law. 2011, 7: 231-249; Mitsilegas, V. The Limits of Mutual Trust in Europe's Area of Freedom, Security and Justice: From Automatic Inter-State Cooperation to the Slow Emergence of the Individual. Yearbook of European Law. 2012, 31: 354-355, and Kuipers, J.-J. The (non) Application of the Charter of Fundamental Rights to a Certificate for the Return of a Child. European Human Rights Law Review. 2012, 4: 397-412, 411-412. However, see ECtHR, Povse v Austria, Decision of 18 June 2013, No. 3890/11, discussed below n 73 .

16 See Recital 12 of the Brussels II bis Regulation, which states that ' $\mathrm{t}$ ] he grounds of jurisdiction in matters of parental responsibility established in the present Regulation are shaped in the light of the best interests of the child, in particular on the criterion of proximity'.

17 See Article 8(1) of the Brussels II bis Regulation.

18 Article 12 of the Brussels II bis Regulation lays down the conditions, under which a national court with jurisdiction in civil proceedings relating to divorce, legal separation and marriage annulment (see Article 3 thereof) may also have jurisdiction in matters of parental responsibility linked to those proceedings.

19 See Article 13(1) of the Brussels II bis Regulation. 
It is worth noting that the Brussels II bis Regulation does not provide a definition of what is to be understood by the 'habitual residence' of the child concerned. That is why in $A^{20}$ the ECJ was called upon to define the content of that concept. In so doing, the ECJ sought to favour both the principle of mutual recognition and the best interests of the child.

At the outset, the ECJ noted that, in the absence of any express reference to the law of the Member States, the terms 'habitual residence' are an autonomous concept ${ }^{21}$. If national law were to define that concept, the free movement of judgments would be hindered as some Member States might have a definition of 'habitual residence' which is too broad, whilst others might choose one which is too narrow. This could lead to situations where several courts of different Member States claim jurisdiction or, conversely, where no court is willing to assume it. Accordingly, an autonomous interpretation of the terms 'habitual residence' ensures the uniform application of Article 8(1) of the Brussels II bis Regulation throughout the Union. Next, by relying on Recital 12 of the Brussels II bis Regulation, the ECJ noted that the concept of 'habitual residence' must be shaped in light of the best interests of the child ${ }^{22}$. This meant that the concept of 'habitual residence' contained in other EU measures could not be applied, by analogy, to the Brussels II bis Regulation ${ }^{23}$. This also implied that a general and abstract rule defining the concept of 'habitual residence' was to be discarded, since that concept 'must be established on the basis of all the circumstances specific to each individual case ${ }^{24}$. The ECJ thus opted for a flexible concept of 'habitual residence'. To that end, it held that the mere physical presence of the child in a Member State is not sufficient to consider him or her a habitual resident of that Member State, but that other factors had to be taken into consideration ${ }^{25}$. The concept of 'habitual residence', the ECJ ruled, 'corresponds to the place which reflects some degree of integration by the child in a social and family environment ${ }^{26}$. Accordingly, the ECJ set out the non-exhaustive criteria that the referring court was to take into consideration when interpreting Article 8(1) of the Brussels II bis Regulation. For example, the national court should look at, in particular, 'the duration, regularity, conditions and reasons for the stay on the territory of a Member State and the family's move to that State, the child's nationality, the place and conditions of attendance at school, linguistic knowledge and the family and social relationships of the child in that State. ${ }^{27}$

It is worth noting that the interpretation adopted by the ECJ is respectful of the multilateral Conventions containing rules on jurisdiction for decisions on custody, to which many or all of the Member States are parties, notably the 1996 Hague Convention

20 See Case C-523/07 $A$ [2009] ECR I-2805.

21 Ibid., para. 34.

22 Ibid., para. 35.

23 Ibid., para. 36.

24 Ibid., para. 37.

25 Ibid., para. 38.

26 Ibid., para. 44.

27 Ibid., para. 44. 
on Jurisdiction, Applicable Law, Recognition, Enforcement and Cooperation in respect of Parental Responsibility and Measures for the Protection of Children (the Child Protection Convention) ${ }^{28}$. It is true that, in contrast to the Opinion of AG Kokott, the ECJ did not examine the relationship between the Brussels II bis Regulation and the abovementioned multilateral Conventions. However, one may argue that the ECJ did implicitly take them into account. The Brussels II bis Regulation is inspired by the Child Protection Convention: both Article 8(1) of the former and Article 51(1) of the latter use 'habitual residence' as the general jurisdiction principle. AG Kokott argued that it was important to define 'habitual residence' consistently with the definition of the same concept set out in the Child Protection Convention, since this would avoid conflicts between courts of the EU Member States and courts of third States parties to that Convention ${ }^{29}$. In this regard, she noted that when drafting the Child Protection Convention, the governments involved believed that, unlike the legalistic concept of domicile, a flexible concept of 'habitual residence' was the most suitable means of guaranteeing the best interests of the child ${ }^{30}$.

It follows from the ruling of the ECJ in $A$ that the principle of legal certainty had to be accommodated with the 'best interests of the child', given that a clear-cut rule defining 'habitual residence' could not ensure that that concept would always convey the actual centre of life of the child concerned, which is to be ascertained by reference to all the relevant circumstances.

In Mercred $^{31}$, the ECJ was again asked to interpret the concept of 'habitual residence' in a rather extreme scenario. The case involved Chloé, a 16-month-old French child, who was lawfully removed from the UK to the Island of Réunion (France) by her mother, who was the only person with rights of custody. Prior to that, Chloé had her habitual residence in England, where her father lived. Four days after her lawful removal, Chloé's father filed applications for parental responsibility, shared residence and rights of access before the High Court. The question was thus whether Chloé could be considered to be a habitual resident of the Island of Réunion, in spite of the fact that she had only been there for four days when the High Court was seised. After recalling its main findings in $A$, the ECJ pointed out that, whilst Article 8(1) of the Brussels II bis Regulation requires more than a mere temporary presence, it 'does not lay down any minimum duration' of $\operatorname{stay}^{32}$. The duration of stay may only serve as an indicator in the assessment of the permanence of residence. What is important, according to the ECJ, is 'that the person concerned has it in mind to establish there the permanent or habitual centre of his

28 The Child Protection Convention is not mentioned in Article 60 but in Article 61 of the Brussels II bis Regulation. The latter provision states that the Brussels II bis Regulation 'shall apply (a) where the child concerned has his or her habitual residence on the territory of a Member State; (b) as concerns the recognition and enforcement of a judgment given in a court of a Member State on the territory of another Member State, even if the child concerned has his or her habitual residence on the territory of a third State which is a contracting Party to the said Convention'.

29 See Opinion of AG Kokott in Case C-523/07 A [2009] ECR I-2805, para. 26.

30 Ibid., para. 31.

31 Case C-497/10 PPU Mercredi [2010] ECR I-14309.

32 Ibid., para. 51. 
interests, with the intention that it should be of a lasting character' ${ }^{33}$. Needless to say, to talk about the 'intentions' of a 16-month-old baby would be impossible. That is why, in relation to young children, who have been lawfully removed, the ECJ stressed the fact that one should examine the integration of their primary carer in his or her social and family environment ${ }^{34}$. For Chloé, this meant that, in addition to the criteria listed in $A$, the referring court had also to examine the degree of integration attained by her mother in the Island of Réunion, by looking, for example, at her mother's reasons to move to her home Member State, the languages known to her or her geographic and family origins ${ }^{35}$.

It follows that the age of the child concerned will determine how the referring court must carry out its examination. The younger the child is, the more important the intentions of his or her primary carer become. Conversely, in respect of an older child, it is possible to establish a connection between him or her and the Member State where he or she intends to live, even if that State is not the one to which his or her primary carer intends to move. Mercredi is an interesting development in the case-law of the ECJ, which shows the importance of allowing room for flexibility when interpreting the concept of 'habitual residence'.

\section{Child abduction}

Unsurprisingly, most of the preliminary questions referred to the ECJ on the Brussels II bis Regulation have been made in child abduction proceedings ${ }^{36}$. In light of Recital 17 of the Brussels II bis Regulation, the 1980 Hague Convention continues 'to apply as complemented by the provisions of this Regulation, in particular Article 11'. Indeed, both legal instruments seek to prevent wrongful removals and retentions from taking place, whilst securing the safe and swift return of the child.

\subsection{The concept of 'wrongful removal or retention'}

The definition of 'wrongful removal or retention' laid down in Article 2(11) of the Brussels II bis Regulation is clearly inspired by Article 3 of the 1980 Hague Convention. In accordance with both Articles, the term 'wrongful removal or retention' refers to situations where the child is removed or retained in breach of rights of custody ${ }^{37}$,

33 Ibid., para. 51.

34 See Lamont, R. Case Note on A. Common Market Law Review. 2010, 47: 235-244, at 240-241 (arguing that ' $[\mathrm{i}] \mathrm{t}$ may be desirable to consider the carer's intentions when assessing the child's habitual residence, because deciding where a child lives may not easily be separated from where its primary carer lives').

35 Case C-497/10 PPU Mercredi [2010] ECR I-14309, para. 51.

36 Case C-195/08 PPU Rinau [2008] ECR I 5271; Case C-403/09 PPU Detiček [2009] ECR I-12193; Case C-211/10 PPU Povse [2010] ECR I-6673; and Case C-491/10 PPU Aguirre Zarraga [2010] ECR I-14247.

37 According to Article 2(11)(a) of the Brussels II bis Regulation, rights of custody may be 'acquired by judgment or by operation of law or by an agreement having legal effect under the law of the Member State where the child was habitually resident immediately before the removal or retention'. 
provided that, at the time of removal or retention, those rights were actually exercised, or would have been exercised, had removal or retention not taken place ${ }^{38}$.

In $M c B$., the ECJ was called upon to interpret Article 2(11). The facts of the case may be summarised as follows. Mr McB. and Ms E. lived together as an unmarried couple in Ireland. They had three children together. By the year 2009, the couple's relationship had deteriorated. In July 2009, Ms E. took a flight to England, taking with her the children. In November 2009, Mr McB. brought an action before the High Court of England and Wales seeking the return of the children to Ireland. In accordance with Article 15 of the 1980 Hague Convention, the High Court requested Mr McB. to obtain a decision or a determination from the Irish authorities declaring that the removal of the children was wrongful within the meaning of Article 3 of the abovementioned Convention. Accordingly, Mr McB. brought an action before the Irish High Court, seeking to obtain such a decision or a determination. However, the action was dismissed on the ground that the removal was not wrongful under the 1980 Hague Convention since, in accordance with Irish law, the natural father of children did not have automatic rights of custody ${ }^{39}$. On appeal, the Irish Supreme Court decided to stay proceedings and to ask the ECJ whether the Brussels II bis Regulation, read in light of Article 7 of the Charter, must be interpreted as precluding a Member State from providing by its law that the acquisition of rights of custody by a child's father, where he is not married to the child's mother, is dependent on the father's obtaining a judgment from a national court with jurisdiction awarding such rights of custody to him, on the basis of which the removal of the child by his or her mother or the retention of that child may be considered wrongful, within the meaning of Article 2(11) of that Regulation ${ }^{40}$.

The ECJ held that Article 2(9) of the Brussels II bis Regulation defined 'rights of custody' as covering 'rights and duties relating to the care of the person of a child, and in particular the right to determine the child's place of residence'. It also observed that 'rights of custody' are an autonomous concept that must be interpreted uniformly throughout the Union ${ }^{41}$. However, the Brussels II bis Regulation does not define the identity of the person who has rights of custody but refers to the laws of the Member State, where the child was habitually a resident immediately before his or her removal or retention. This means that it is for national law to determine 'the conditions under which the natural father acquires rights of custody in respect of his child, within the meaning of Article 2(9) of [the Brussels II bis Regulation], and which may provide that his acquisition of such rights is dependent on his obtaining a judgment from the national court with jurisdiction awarding such rights to him. ${ }^{42}$

38 According to Article 2(11) (b) of the Brussels II bis Regulation, rights of custody may be exercised either jointly or alone. 'Joint custody' takes place 'when, pursuant to a judgment or by operation of law, one holder of parental responsibility cannot decide on the child's place of residence without the consent of another holder of parental responsibility'.

39 Case C-400/10 PPU $M c B$ [2010] ECR I-8965, para. 48. In accordance with Irish law, the natural father is required to reach an agreement with the mother or to obtain a court judgment.

$40 \quad$ Ibid., para. 25.

41 Ibid., para. 41.

42 Ibid., para. 43. 
In light of the foregoing, the ECJ found that, under the Brussels II bis Regulation, the breach of (existing) rights of custody, conferred by the relevant national law, is a prerequisite in order for a removal to be considered as wrongful ${ }^{43}$. Next, the ECJ went on to determine whether such interpretation of the Brussels II bis Regulation was consistent with the Charter, in particular, with Articles 7 and 24 thereof ${ }^{44}$. As to Article 7 of the Charter, the ECJ noted that it is almost identical to Article 8 of the ECHR ${ }^{45}$. In accordance with Article 52(3) of the Charter, the meaning and scope of the rights contained in Article 7 thereof are therefore the same as those laid down in Article 8 of the European Convention on Human Rights (the ECHR) ${ }^{46}$. Referring to the case-law of the European Court of Human Rights (the ECtHR) ${ }^{47}$, the ECJ held that the fact that rights of custody automatically belong to the mother but not to the natural father is not contrary to the latter's right to a private and family life ${ }^{48}$, in so far as he has 'the right to apply to the national court with jurisdiction, before the removal, in order to request that rights of custody in respect of his child be awarded to him'49. As to Article 24 of the Charter, the ECJ held that the fact that the natural father possesses rights of custody only as the result of a court judgment enables national courts to take a decision on the custody of the child which is apt to protect the child's best interests. Indeed, national courts may take into account all the relevant facts, in particular 'the circumstances surrounding the birth of the child the nature of the parents' relationship, the relationship of the child with each parent, and the capacity of each parent to take the responsibility of caring for the child. ${ }^{50}$ For the case at hand, the approach followed by the ECJ meant that Ms E. did not commit a wrongful removal within the meaning of the Brussels II bis Regulation. However, that circumstance 'does not deprive [Mr McB.] of the possibility of exercising his right to submit an application to obtain rights of custody thereafter in respect of [his children] or rights of access to [them]. ${ }^{51}$

\subsection{Article 11 of the Brussels II bis Regulation: a compromise solution}

Article 11 of the Brussels II bis Regulation is the result of a political compromise between two dividing camps. On the one hand, a group of Member States supported the

43 Ibid., para. 44.

44 In this regard, Mr McB. argued that 'rights of custody' should be interpreted as meaning that such rights are acquired by a natural father by operation of law in a situation, where he and his children have a family life, which is the same as that of a family based on marriage. Case C-400/10 PPU McB [2010] ECR I-8965, para. 47.

45 Ibid., para. 53. The only difference is that, whilst Article 7 of the Charter refers to 'the right to respect for his or her communications', the wording of Article 8 of the ECHR uses the expression 'the right to respect for his correspondence'.

46 This is so notwithstanding the fact that EU law may grant a greater protection. See Article 52(3) of the Charter.

47 See the ECtHR, Guichard v France, ECHR 2003-X 714; see also, to that effect, the ECtHR, Balbontin v United Kingdom, Judgment of 14 September 1999, No 39067/97.

48 Case C-400/10 PPU McB [2010] ECR I-8965, para. 54.

49 Ibid., para. 55.

50 Ibid., para. 62.

51 Ibid., para. 58. 
status quo. Given that the system set out in the 1980 Hague Convention had given fairly good results ever since it entered into force, in their view, there was no need for new legislation at $\mathrm{EU}_{\text {level }}{ }^{52}$. On the other hand, another group of Member States argued that the effectiveness of the 1980 Hague Convention needed to be strengthened by having recourse to the principle of mutual recognition of judgments and by eliminating the need for exequatur. Most importantly, they posited that the exception to the return order set out in Article 13(b) of the 1980 Hague Convention had given rise to abuses. That provision of the 1980 Hague Convention states that the requested State is not bound by the return order if the person, institution or body, which opposes the return of the child, establishes that 'there is a grave risk that his or her return would expose the child to physical or psychological harm or otherwise place the child in an intolerable situation'.

In order to break the deadlock between those two camps, Article 11 of the Brussels II bis Regulation was drafted in such a way as to guarantee 'continuity and change'. As McEleavy states ${ }^{53}$, '[t]he summary return mechanism of the [1980] Hague Convention was preserved for [EU] child abduction cases but the reformers got a strict transfer of jurisdiction provision to secure the status of the State of habitual residence'. Indeed, Article 11(2) of the Brussels II bis Regulation refers to Articles 12 and 13 of the 1980 Hague Convention. This means that the holder of rights of custody seeking the return of the child must fulfil the conditions laid down in Article 12 of the 1980 Hague Convention. Notably, the holder of the rights of custody has, as a general rule, one year from the date of the wrongful removal or retention to bring proceedings before the judicial or administrative authority of the Contracting State where the child is present ${ }^{54}$. In the same way, unless 'it is established that adequate arrangements have been made to secure the protection of the child after his or her return' ${ }^{55}$, the requested State may still rely on the exception set out in Article 13(b) of the 1980 Hague Convention.

52 Ripley, P. A Defence of the Established Approach to the Grave Risk Exception in the Hague Child Abduction Convention. Journal of Private International Law. 2008, 4: 443-477, at 445. He argues that 'the Brussels II bis Regulation represents an unnecessary attempt to further limit the situations in which a non-return order will be made. The re-evaluation mechanism it puts in place where abducted children are not returned following Convention proceedings imperils the comity and mutual trust established between courts in contracting states to the Convention over the past 20 years'. It is worth noting that P. Ripley follows a 'purely' private international law understanding of the principle of mutual trust. See above n 12.

53 See McEleavy, P. The New Child Abduction Regime in the European Union: Symbiotic Relationship or Forced Partnership? Journal of Private International Law. 2005, 1: 5-33, at 14.

54 But see the second paragraph of Article 12 of the 1980 Hague Convention, which states that ' $[t]$ he judicial or administrative authority, even where the proceedings have been commenced after the expiration of the period of one year [...], shall also order the return of the child, unless it is demonstrated that the child is now settled in its new environment'.

55 See Article 11(4) of the Brussels II bis Regulation. See McEleavy, P. The New Child Abduction Regime in the European Union: Symbiotic Relationship or Forced Partnership? Journal of Private International Law. 2005, 1: 5-33, at 26 (noting that Article 11(4) 'has the potential to bring a most welcome benefit for it does not make the assumption that children will be protected upon return, rather it has to be shown that adequate arrangements have been made. It is to be hoped, therefore, that this will encourage a more proactive approach by applicants and the authorities in requesting States to address any concerns which might exist'). 


\subsection{The competent court in cases of child abduction}

As a result of the political compromise described above, the transfer of jurisdiction, resulting from a wrongful removal or retention is subject to strict requirements. In this regard, Article 10 of the Brussels II bis Regulation provides that in case of a wrongful removal or retention of the child, "the courts of the Member State where the child was habitually resident immediately before the wrongful removal or retention shall retain their jurisdiction'. Article 10 sets out only two exceptions to such retention of jurisdiction. First, Article 10(a) provides that jurisdiction may be transferred, where (1) the child is a habitual resident in another Member State, and (2) the holder of rights of custody has acquiesced in the removal or retention. Second, in accordance with Article 10 (b), a transfer of jurisdiction may occur, where (1) the child is a habitual resident in another Member State, (2) he or she has settled there, (3) the holder of rights of custody has known of his or her whereabouts for a period of at least one year, and at least one of the following conditions is met:

'(i) within one year after the holder of rights of custody has had or should have had knowledge of the whereabouts of the child, no request for return has been lodged before the competent authorities of the Member State where the child has been removed or is being retained;

(ii) a request for return lodged by the holder of rights of custody has been withdrawn and no new request has been lodged within the time limit set in paragraph (i);

(iii) a case before the court in the Member State where the child was habitually resident immediately before the wrongful removal or retention has been closed pursuant to Article 11(7);

(iv) a judgment on custody that does not entail the return of the child has been issued by the courts of the Member State where the child was habitually resident immediately before the wrongful removal or retention'.

In Povse, ${ }^{56}$ the ECJ was asked to interpret Article 10(b)(iv). The facts of the case involved the wrongful removal of Sofia from Italy, a four-year old born to an Italian father, Mr Alpago, and an Austrian mother, Ms Povse. The wrongful removal took place in February 2008, when Ms Povse and her daughter left Italy - the Member State, where the child was habitually resident immediately before the wrongful removal - to stay permanently in Austria. That removal was in breach of a provisional decision of the Tribunale per I Minorenni di Venezia which prohibited the mother from leaving Italy with the child. However, in May 2008, the same Tribunale revoked its previous decision and adopted new provisional measures allowing Sofia to stay in Austria. Once settled in Austria, Ms Povse sought to obtain the custody of Sofia before the Bezirksgericht Judenburg, which held that, in accordance with Article 15 of the Brussels II bis Regulation, it enjoyed jurisdiction and requested the Tribunale per I Minorenni di Venezia to decline jurisdiction. However, the latter refused to do so and, in July 2009, ordered the immediate return of Sofia to Italy. In August 2009, the Bezirksgericht 
Judenburg granted the provisional custody of Sofia to Ms Povse. In September 2009, Mr Alpago sought to enforce the judgment of the Tribunale per I Minorenni di Venezia of July 2009 in Austria. The Austrian court refused to enforce that judgment on the ground that the return of the child to Italy would represent a grave risk of psychological harm to her. On appeal, the Oberster Gerichtshof sought guidance from the ECJ. It asked whether a provisional decision, such as that of the Tribunale per I Minorenni di Venezia of May 2008, could be considered as 'a judgment on custody that does not entail the return of the child' within the meaning of Article 10(b)(iv) of the Brussels II bis Regulation. Such a reading of Article 10(b)(iv) would mean that the Tribunale per I Minorenni di Venezia had declined its jurisdiction in favour of the Austrian courts.

The ECJ made clear that the Brussels II bis Regulation seeks to deter child abduction and to obtain the child's return without delay ${ }^{57}$. Since the wrongful removal or retention of a child may not, in principle, have the effect of transferring jurisdiction, the two exceptions contained in Articles 10(a) and 10(b) thereof should be interpreted strictly ${ }^{58}$. Accordingly, the ECJ held that a provisional measure adopted by the courts of the Member State where the child was habitually resident immediately before the wrongful removal or retention could not be considered as 'a judgment on custody that does not entail the return of the child [that] has been issued [by those courts]', as provided by Article 10(b)(iv) of the Brussels II bis Regulation. On the contrary, the application of the exception to the retention of jurisdiction laid down in Article 10(b)(iv) was limited to final judgments issued by the courts of the Member State of origin. Otherwise, the ECJ reasoned, those courts would be deterred from issuing provisional measures, the absence of which could adversely affect the interests of the child ${ }^{59}$.

\subsection{The return of the child}

Moreover, in order to satisfy the vindications of the Member States seeking to enhance the return mechanism of the 1980 Hague Convention, Article 11(8) of the Brussels II bis Regulation provides that an order on non-return pursuant to Article 13 of the said Convention may be overridden by 'any subsequent judgment which requires the return of the child issued by a court having jurisdiction under this Regulation'. Those subsequent judgments 'shall be enforceable in accordance with Section 4 of Chapter III [of the said Regulation] in order to secure the return of the child'. Article 42(1) of the Brussels II bis Regulation eliminates the need for special exequatur proceedings for the recognition and enforcement of a judgment entailing the return of a child which is issued pursuant to Article 11(8) thereof. Once a certificate of that judgment is delivered by the judge of origin in accordance with the requirements listed in Article 42(2) of the Brussels II bis Regulation, all possibilities of opposition are excluded.

In Rinau, the ECJ provided some clarifications as to the interpretation of Articles 11(8), 40(1)(b) and 42(2) of the Brussels II bis Regulation. In that case, the Lithuanian

57 Ibid., para. 43.

58 Ibid., para. 45.

59 Ibid., para. 47. 
Supreme Court was seised of an application for the non-recognition of a judgment of a German court, awarding custody of a child to her father, who lived in Germany, and ordering her mother, who lived in Lithuania, to return the child to him. At the outset, the ECJ observed that the enforcement of a judgment issued pursuant to those provisions by the court of the Member State where the child was habitually resident immediately before the wrongful removal or retention enjoys 'procedural autonomy' ${ }^{60}$. This means that, unlike the 'general' procedure laid down in Section 2 of Chapter III of the Brussels II bis Regulation, Articles 11(8), 40(1)(b) and 42(2) thereof set out a special procedure which seeks to guarantee the immediate return of the child wrongfully removed or retained, by excluding any appeal against the issuing of a certificate ${ }^{61}$ and by precluding parties from opposing its recognition ${ }^{62}$. The party opposing recognition may only bring an action seeking rectification of the certificate before the courts of the Member State of origin and in accordance with the laws thereof. Next, before a certificate based on Article 42(2) of the Brussels II bis Regulation may be issued by the Member State of origin, the holder of rights of custody of the child unlawfully removed must first receive a negative answer from the authorities of the Member State where that child is present. That negative answer is to be delivered in the form of an order on non-return pursuant to Article 13 of the 1980 Hague Convention ${ }^{63}$. To this effect, in accordance with both Article 11 of the 1980 Hague Convention and Article 11(3) of the Brussels II bis Regulation, the authorities of the Member State where the child is present must act expeditiously. They must issue a judgment or decision no later than six weeks after the application is lodged, unless exceptional circumstances make this impossible ${ }^{64}$. But what happens if such an order is subsequently suspended, overturned, set aside or, in any event, has not become res judicata or has been replaced by a decision, ordering the return of the child, which has not effectively taken place? May the court of the

60 Case C-195/08 PPU Rinau [2008] ECR I 5271, para. 63.

61 Ibid., para. 85.

62 Ibid., para. 68.

63 Ibid., para. 59.

64 If the authorities of the Member State of enforcement do not act expeditiously, they will not only breach Article 11(3) of the Brussels II bis Regulation, but also the fundamental rights of the parent suffering from the wrongful removal or retention. See, to this effect, the ECtHR, Karoussiotis v Portugal, Judgment of 1 February 2011, No.23205/08, para. 88 et seq. The facts of the case involved the wrongful retention of a child by his father in Portugal. Prior to that, the child had lived with his mother in Germany. In March 2005, the mother of the child requested the German federal prosecutor to bring proceedings on the basis of the 1980 Hague Convention, with a view to having the child returned to Germany. The request was made in October of the same year. However, it was not until January 2009, when the Court of Appeal of Guimarães ruled that, on the basis of Article 13(b) of the 1980 Hague Convention, the child was not to be returned to Germany, given that, due to the passing of time, he had settled well into the new environment and developed an emotional relationship with his Portuguese great-grandmother. Parallel to the 1980 Hague Convention proceedings, proceedings relating to parental responsibility for the child which had begun in 2005 were still pending before the same Court of Appeal. The ECtHR reasoned that the fact that Portuguese courts had taken almost four years to rule on the return of the child to Germany and that proceedings on matters relating to parental responsibility were still pending after more than five years, constituted a violation of Article 8 of the ECHR. Indeed, because of the excessive length of judicial proceedings, the relationship between the child and his mother was, if not destroyed, severely damaged. 
Member State of origin still issue a certificate based on Article 42(2) of the Brussels II bis Regulation? In light of 'the interpretation that best ensures the effectiveness of [EU] law' ${ }^{65}$, the ECJ replied in the affirmative. Otherwise, it reasoned, "there would be a risk that the Regulation would be deprived of its useful effect, since the objective of the immediate return of the child would remain subject to the condition that the redress procedures allowed under the domestic law of the Member State in which the child is wrongfully retained have been exhausted' ${ }^{66}$.

In Povse, the ECJ was also called upon to interpret the terms 'any subsequent judgment which requires the return of the child' contained in Article 11(8) of the Brussels II bis Regulation. In particular, the referring court asked whether those terms had to be read so as to limit the automatic recognition and enforcement of judgments set out in Section 4 of Chapter III of the Brussels II bis Regulation to final judgments on rights of custody rendered by the court of the Member State where the child was habitually resident immediately before the wrongful removal or retention. The ECJ replied in the negative. First, the ECJ noted that such a reading of Article 11(8) of the Brussels II bis Regulation had no basis in its wording, since the latter provision clearly refers to 'any subsequent judgment which requires the return of the child' ${ }^{67}$. Second, no provision on the enforcement of a judgment issued on the basis of Article 11(8) refers to such requirement ${ }^{68}$. Third, referring to its previous ruling in Rinau, the ECJ recalled that the Brussels II bis Regulation seeks the swift return of the child wrongfully removed or retained ${ }^{69}$. If the fact of obtaining a final judgment issued by the court enjoying jurisdiction by virtue of the Brussels II bis Regulation operated as a prerequisite to the application of Article 11(8), then that court would rush to take a final decision on rights of custody, despite lacking either all the relevant information or the material needed for that purpose. Such a reading of Article 11(8) would be contrary to the best interests of the child. Last, but not least, the ECJ reasoned that, since the system set up by the EU legislator rests on the premise that wrongful removal or retention is detrimental to the best interests of the child, the longer the separation between the child and the father or the mother suffering from the wrongful removal or retention lasts, the more adversely affected the fundamental rights of the child will be ${ }^{70}$. Accordingly, in light of Article 24 of the Charter, the court of the Member State where the child was habitually resident immediately before the wrongful removal or retention may issue a judgment on the basis of Article 11(8) of the Brussels II bis Regulation, regardless of whether it has previously rendered a final judgment on the rights of custody of that child.

In addition, in Povse, the ECJ was called upon to determine whether a judgment ordering the return of the child issued by a court of the Member State of origin on the basis of Article 11(8) of the Brussels II bis Regulation could be overridden by a

66 Ibid., para. 81.

67 Case C-211/10 PPU Povse [2010] ECR I-6673, para. 52.

68 Ibid., para. 54.

69 Ibid., para. 62.

70 Ibid., para. 64. 
subsequent judgment of a court of the Member State of enforcement. Again referring to Rinau, the ECJ held that there is nothing the Member State of enforcement can do to oppose recognition and enforcement of a certified judgment issued on the basis of Article 11(8). Stated simply, recognition is automatic. The only means available to the party opposing recognition is to bring an action seeking the rectification of the certificate before the competent court of the Member State of origin and in accordance with the laws thereof ${ }^{71}$. However, such an action cannot amount to an appeal, which is ruled out by Article 43(2) of the Brussels II bis Regulation. Rectification is thus limited to verifying that no material error occurred, i.e. to ascertaining whether the certificate correctly reflects the judgment ${ }^{72}$. This is without prejudice to Article 47(2) which provides that a certified judgment is not enforceable if it is irreconcilable with a subsequent enforceable judgment of the competent court of the Member State of origin ${ }^{73}$.

More recently, in Aguirre Zarraga ${ }^{74}$, concerning the non-return of a child from Germany to Spain, the Oberlandesgericht Celle asked, in essence, whether the certificate provided for by Article 42 of the Brussels II bis Regulation ordering the return of a child could be disregarded by a court in the Member State of enforcement in circumstances, where its issue amounted to a serious violation of fundamental rights, notably Article 24 of the Charter, or where that certificate contained a statement that was manifestly incorrect. In particular, the referring court asked whether it could oppose the enforcement of a judgment ordering the return of a child where - contrary to what is provided for by Article 42(2)(a) of the Brussels II bis Regulation - that child had not been given the opportunity to be heard.

After recalling its main findings in Rinau and Povse, the ECJ held that 'the first subparagraph of Article 42(2) in no way empowers the court of the Member State of enforcement to review the conditions for the issue of that certificate as stated therein', given that such power could undermine the effectiveness of the system set up by the Brussels II bis Regulation ${ }^{75}$. Since recognition of a judgment certified pursuant to the requirements laid down in Article 42(2) is automatic, there is nothing a court of the Member State of enforcement can do to oppose it. Moreover, unlike the recognition

71 Ibid., para. 74.

72 Ibid., para. 71.

73 See also the ECtHR, Povse v. Austria, Decision of 18 June 2013, No. 3890/11. In that case, Ms Povse and her daughter argued that the Austrian court decisions - which in application of the ECJ's ruling in Case C 211/10 PPU Povse [2010] ECR I-6673 ordered the return of the child to Italy - had violated their right to respect for their family life as guaranteed by Article 8 of the ECHR. However, by applying the 'Bosphorus presumption' (Bosphorus Hava Yolları Turizm ve Ticaret Anonim Şirketi v. Ireland [GC], No. 45036/98, para. 155 et seq., ECHR 2005-VI) according to which 'the protection of fundamental rights afforded by the European Union is in principle equivalent to that of the Convention system as regards both the substantive guarantees offered and the mechanisms controlling their observance', the ECtHR declared their application to be inadmissible. It held that the 'Bosphorus presumption' applied to the case at hand, given that the Austrian courts did no more than implement the legal obligations flowing from Austria's membership of the EU, without exercising any discretion, when ordering the enforcement of the Tribunale per I Minorenni di Venezia's return order of 23 November, 2011.

74 Case C-491/10 PPU Aguirre Zarraga [2010] ECR I-14247.

75 Ibid., para. 54-55. 
of judgments adopted in accordance with the provisions of Chapter III, Section 1 of the Brussels II bis Regulation which allow the Member State of enforcement to rely on public policy considerations and on the fundamental rights of the child concerned to oppose recognition ${ }^{76}$, the same does not hold true for the provisions of Chapter III, Section 4 of the same Regulation ${ }^{77}$. The fact that the court of the Member State of enforcement lacks the powers to review a certified judgment adopted in accordance with Article 42(2) does not mean, however, that the fundamental rights of the child concerned are deprived of judicial protection. First, the ECJ recalled that the system set up by the Brussels II bis Regulation rests on the principle of mutual trust. In the realm of fundamental rights, this means that it is presumed that all national courts provide an equivalent and effective level of judicial protection ${ }^{78}$. Second, the ECJ ruled that Article 42(2) is to be interpreted in light of Article 24 of the Charter. In this regard, the ECJ pointed out that the Charter does not impose an absolute obligation to hear the child in every single case of wrongful removal or retention. Indeed, under some circumstances, the hearing of the child can actually be detrimental to his or her psychological health, as he or she may be exposed to the underlying tensions associated with the judicial proceedings concerning the award of rights of custody ${ }^{79}$. It is thus for the court of the Member State of origin to examine, when issuing a certificate on the basis of Article 42(2) of the Brussels II bis Regulation, whether hearing the child is in his or her best interests ${ }^{80}$. If so, then it must also make sure that the child enjoys a genuine and effective opportunity to express himself or herself freely. Moreover, if one of the parties considers that the court of the Member State of origin has issued a certificate in violation of Article 42(2)(a), then it must bring legal proceedings before the courts of that Member State. As mentioned above, that party may not bring an appeal against the certified judgment, ordering the return of the child (either before the courts of the Member State of origin or of the Member State of enforcement $)^{81}$. However, a violation of the child's right to be heard may provide sufficient grounds to overturn the final or provisional judgment awarding rights of custody ${ }^{82}$.

\section{Provisional measures}

As mentioned above, Article 8(1) of the Brussels II bis Regulation grants general jurisdiction on matters of parental responsibility to the courts of the Member State where the child has his or her habitual residence. In cases of child abduction, Article 10 thereof

76 See Article 23 of the Brussels II bis Regulation.

77 Case C-491/10 PPU Aguirre Zarraga [2010] ECR I-14247, para. 58.

78 Ibid., paras. 59 and 61.

79 Ibid., para. 64.

80 Ibid., para. 68.

81 See, in this regard, Case C-211/10 PPU Povse [2010] ECR I-6673, para. 71.

82 Case C-491/10 PPU Aguirre Zarraga [2010] ECR I-14247, para. 72. 
grants jurisdiction to the courts of the Member State where the child was habitually resident immediately before the wrongful removal or retention.

However, there can be urgent situations where the child is staying in a Member State other than that where he or she habitually resides (or used to reside just before the wrongful removal or retention), and the adoption of measures on parental responsibility is nevertheless required. This can be the case where, for example, the parents of the child are unable to exercise their rights of custody, because they have either suffered an accident or passed away when staying in another Member State. Bearing these urgent cases in mind, the authors of the Brussels II bis Regulation drafted Article 20(1) which empowers the court of the Member State where the child is present to adopt provisional measures on parental responsibility. Once the court of the Member State having jurisdiction under the Brussels II bis Regulation has taken the measures it considers appropriate, Article 20(2) thereof provides that the provisional measures adopted under Article 20(1) no longer apply.

In Detiček, the ECJ was asked to clarify the scope of Article 20. The facts may be summarised as follows. In the course of divorce proceedings between Ms Detiček, a Slovenian national, and Mr Sgueglia, an Italian national, the competent court in Tivoli (Italy) provisionally granted the custody of their daughter to Mr Sgueglia. On the same day this decision was issued, Ms Detiček left Italy with her daughter to go to Slovenia. With a view to having his daughter returned to Italy, Mr Sgueglia sought to enforce the order of the Italian court in Slovenia. The order of the Italian court was declared enforceable in Slovenia but its enforcement was suspended until final disposal of the main proceedings. For her part, Ms Detiček obtained a provisional and protective measure from the Regional Court of Maribor (Slovenia) giving her custody of the child. The Regional Court of Maribor based its jurisdiction to adopt such a measure on Article 20 of the Brussels II bis Regulation, holding that there had been a change of circumstances that militated against removing the child from her social environment in Slovenia. This decision was challenged by Mr Sgueglia before the Court of Appeal of Maribor, which sought guidance from the ECJ. Hence, the questions referred to the ECJ boiled down to determining whether the Regional Court of Maribor had made an appropriate use of the provisions conferring exceptional jurisdiction laid down in Article 20 of the Regulation.

At the outset, the ECJ ruled that, since the adoption of provisional measures in accordance with Article 20 of the Brussels II bis Regulation is 'an exception to the system of jurisdiction laid down [thereby], that provision must be interpreted strictly ${ }^{83}$. In this regard, in recalling its previous ruling in $A^{84}$, the ECJ stated that it follows from the very wording of Article 20 of the Brussels II bis Regulation that the adoption of provisional measures by the court of the Member State where the child is present is subject to three cumulate conditions, namely: the measures concerned must be urgent, must be taken in respect of persons or assets in the Member State where those courts are situated, and must be provisional ${ }^{85}$. As to the condition of urgency, the ECJ held

83 Case C-403/09 PPU Detiček [2009] ECR I 12193, para. 38.

84 Case C-523/07 A [2009] ECR I-2805, para. 47.

85 Case C-403/09 PPU Detiček [2009] ECR I 12193, para. 39. 
that a change of circumstances resulting from a gradual process such as the child's integration into her new environment was not a sufficient ground for the court of the Member State where the child is present to adopt provisional measures under Article 20 of the Brussels II bis Regulation. First, such a reading of Article 20 would be contrary to the principle of mutual recognition, since it would encourage the courts of the Member State where the child is present to block the enforcement of a judgment that has been declared enforceable in accordance with Article 28(1) of that Regulation ${ }^{86}$. Second, such a reading of Article 20 would not deter wrongful removals or retentions, but would actually consolidate them, as the position of the parent responsible for the abduction of the child would be strengthened ${ }^{87}$. Finally, the ECJ referred to Article 24(3) of the Charter. It held that a wrongful removal adversely affects the fundamental rights of the child concerned, as he or she is unilaterally deprived of maintaining on a regular basis a personal relationship and contact with both parents. To interpret Article 20 in a way that favours the parent responsible for the wrongful removal would be tantamount to interpret that provision contrary to the Charter ${ }^{88}$. Although it is true that, in some circumstances, maintaining on a regular basis a personal relationship and contact with both parents must be weighed against other legitimate interests of the child concerned ${ }^{89}$, it is, in principle, for the court having jurisdiction as to the substance of the matter in accordance with the provisions of the Brussels II bis Regulation to strike such a balance.

Moreover, in accordance with Article 15 of the Brussels II bis Regulation, 'the courts of a Member State having jurisdiction as to the substance of the matter may, if they consider that a court of another Member State, with which the child has a particular connection, would be better placed to hear the case, or a specific part thereof, and where this is in the best interests of the child' request that other court to assume jurisdiction. However, the Brussels II bis Regulation is silent as to whether the court of the Member State where the child is present, after adopting a provisional or protective measure under Article 20, must automatically transfer the case to the court of another Member State having jurisdiction. In the same way, if a court declares of its own motion that it lacks jurisdiction, the Regulation says nothing as to whether the case must automatically be transferred to a court of another Member State. In $A$, the ECJ refused to interpret the Brussels II bis Regulation in a way that imposes the automatic transfer of jurisdiction.

\section{Ibid., para. 47.}

87 Ibid., para. 49.

88 Case C-403/09 PPU Detiček [2009] ECR I 12193, para. 57.

89 Ibid., para. 60. See, in this regard, the ECtHR, Neulinger and Shuruk v. Switzerland [GC], Judgment of 6 July 2010, no. 41615/07, ECHR 2010. The facts of the case involved the unlawful removal of a child by his mother from Israel to Switzerland. The father of the child, whose behaviour as a parent was everything but exemplary, filed an application before the Swiss courts seeking the return of the child in accordance with the 1980 Hague Convention. His application was upheld by the Swiss courts. However, the ECtHR held that, in spite of the fact that a wrongful removal had taken place, the return of the child would breach Article 8 of the ECHR, since it would cause him severe psychological and emotional damage. Therefore, in order to comply with the ECHR, Switzerland could not order the return of that child. It follows that, in order to comply with Article 8 of the ECHR, Switzerland had no choice but to rely on the exception laid down in Article 13(b) of the 1980 Hague Convention. 
Nevertheless, where the best interests of the child so require, the court that has taken provisional or protective measures must inform the court of another Member State having jurisdiction ${ }^{90}$. The same obligation applies to the court, which declares of its own motion that it lacks jurisdiction ${ }^{91}$.

In Purrucker $I I^{92}$, the ECJ had to determine whether the adoption of provisional measures under Article 20 of the Brussels II bis Regulation could trigger the application of the lis pendens rules laid down in Article 19 thereof. The facts of the case may be summarised as follows. From mid-2005 to early 2007, Mr Vallés Pérez and Ms Purrucker lived together as an unmarried couple in Spain. In May 2006, Ms Purrucker gave birth to boy-girl twins who were born prematurely. The boy, Merlin, was able to leave hospital in September of that year. By contrast, the girl, Samira, had to stay in hospital until March 2007. By the time the twins were born, the relationship between Mr Vallés Pérez and Ms Purrucker had deteriorated. In February 2007, after concluding an agreement before a notary which provided that both parents would have custody of and parental responsibility for the twins and fixed Germany as their permanent place of residence, Ms Purrucker left for Germany with her son Merlin. Samira had to stay in Spain because she still required surgery. In Ms Purrucker's understanding of the agreement, Samira was to be brought to Germany after she left hospital.

However, no longer wishing to follow the agreement signed before a notary, $\mathrm{Mr}$ Vallés Pérez brought an action before a Spanish court seeking interim measures and, in particular, provisional rights of custody in respect of his children. As a provisional measure, the Spanish court ordered the return of Merlin to Spain. Accordingly, $\mathrm{Mr}$ Vallés Pérez sought to enforce the judgment of the Spanish court in Germany. In the course of these proceedings, the Bundesgerichtshof referred a question to the ECJ which led to Purrucker $1^{93}$. In that case, the ECJ held that the provisions laid down in Article 21 et seq. of the Brussels II bis Regulation were not applicable to provisional measures adopted under Article 20 of that Regulation, but only to judgments on the substance ${ }^{94}$.

For her part, Ms Purrucker brought an action before the Amtsgericht Stuttgart seeking custody of her children. Having doubts as to its international jurisdiction, the Amtsgericht Stuttgart asked the ECJ how 'the court first seised' was to be determined for the purposes of the lis pendens rule set out in Article 19 of the Brussels II bis Regulation. The ECJ held that the lis pendens rule contained therein does not apply in relation to the court of a Member State which is called upon to grant only provisional measures ${ }^{95}$.

90 Case C-523/07 $A$ [2009] ECR I-2805, para. 64.

91 Ibid., para. 70.

92 Case C-296/10 Purrucker II [2010] ECR I-11163.

93 Case C-256/09 Purrucker I [2010] ECR I-07353.

94 Ibid, para. 82 et seq.

95 Case C-296/10 Purrucker II [2010] ECR I-11163, para. 73-77. But the ECJ stressed the fact that it is not the nature of the proceedings before a national court that determines the application of the lis pendens rule contained in Article 19 of the Brussels II bis Regulation. For example, prior to ruling on the substance of the matter, national law may require the adoption of provisional measures. Hence, the application of Article 19 of the Regulation requires national courts to engage in a comparative analysis of the claims of the respective applicants. To that effect, if the facts of the case and the claim of the applicant reveal no 
The reasons are twofold ${ }^{96}$. First, referring to Purrucker $I^{97}$, the ECJ held that '[i]t is evident from the position of Article 20 in the structure of [the Brussels II bis Regulation] that it cannot be regarded as a provision which determines substantive jurisdiction for the purposes of that [R] egulation'. Second, in light of Article 20(2) of the Brussels II bis Regulation, provisional measures cease to produce effects as soon as appropriate provisional or definitive measures are adopted by the national court having substantive jurisdiction under that Regulation. It follows that where the court first seised by a party is called upon to grant only provisional measures, then the court of another Member State subsequently seised by the other party - in compliance with the Brussels II bis Regulation - has jurisdiction to rule on the substance of the matter and, as the case may be, to provide interim relief.

\section{Cooperation between national authorities: the cross-border placement of a child}

Sadly, children may suffer from a mental or physical illness which makes them particularly vulnerable and in need of exceptional protection. Where a child experiences repeated episodes of risk-taking, violence, aggression and self-harm, the holder of parental responsibility may, for the child's safety, decide to send him or her to a secure care institution. Where no suitable institution is available in the home Member State, the child's best interests may militate in favour of placing him or her in a secure care institution located in another Member State.

In this regard, Article 56(1) of the Brussels II bis Regulation provides that ' $[\mathrm{w}]$ here a court having jurisdiction under Articles 8 to 15 contemplates the placement of a child in institutional care or with a foster family and where such placement is to take place in another Member State, it shall first consult the central authority or other authority having jurisdiction in the latter State where public authority intervention in that Member State is required for domestic cases of child placement'. If the law of the requested Member State provides for such intervention, Article 56(2) makes that placement conditional on obtaining the consent of the competent authority of that State ${ }^{98}$.

In Health Service Executive ${ }^{99}$, the ECJ was, for the first time, called upon to interpret the abovementioned provision of the Brussels II bis Regulation. The facts of the case are as follows. S.C., a child of Irish nationality was, from 2000 until 2011, placed in the voluntary care of the Health Service Executive (the HSE), the statutory authority with

elements indicating that the court first seised is called upon to exercise its substantive jurisdiction, then the lis pendens rule contained in Article 19 does not apply.

96 Ibid., para. 70-71.

97 Case C-256/09 Purrucker I [2010] ECR I-07353, para. 61.

98 Where such intervention is not required by the law of the requested State, Article 56(4) provides that the court having jurisdiction under Articles 8 to 15 'shall so inform the central authority or other authority having jurisdiction in the [requested] State'.

99 Case C-92/12 PPU Health Service Executive, Judgment of 26 April 2012, not yet reported. 
responsibility for children taken into public care in Ireland. Taking the view that S.C. had repeatedly absconded from where she had been placed and attempted on several occasions to take her own life, the HSE requested that the High Court ordered S.C.'s placement in the secure care institution situated in England which it had chosen ${ }^{100}$. In December 2011, the High Court, invoking its jurisdiction to exercise parental responsibility, ruled that the welfare of S.C. compelled it to transfer the child, as a matter of urgency, to a secure institution in England providing therapeutic and educational care. S.C. was, thus, transferred to the chosen secure care institution and placed in 'secure care', which, under Irish law, involves compulsory detention. In its order of placement, the High Court stated that it had obtained the consent of UK authorities required by Article 56(2) of the Brussels II bis Regulation. However, the question of bringing any proceedings in England and Wales for recognition and a declaration of enforceability of the placement order under that Regulation had not been addressed.

Subsequently, in order to assess how best to protect the interests of the child in the main proceedings and to decide whether her placement in the secure care institution situated in England should be continued, the High Court decided to seek guidance from the ECJ. First, it asked whether the order of placement at issue in the main proceedings fell within the scope of application of the Brussels II bis Regulation, since it provided for a measure of deprivation of liberty. At the outset, the ECJ noted that ' $[\mathrm{t}]$ he concept of "civil matters" for the purposes of Article 1(1)(b) of the Brussels II bis Regulation must be interpreted as meaning that it may even include measures which, from the point of view of the legal system of a Member State, fall under public law. ${ }^{101}$ In light of Article 1(2)(d) of the Brussels II bis Regulation, those matters may deal with 'the placement of the child in a foster family or in institutional care'. It is true that neither Article 1(2)(d) nor Article 56 of the Brussels II bis Regulation expressly refers to the placement of a child which includes a period of deprivation of liberty for therapeutic and educational purposes. However, the ECJ recalled that the list contained in Article 1(2) of the Regulation is not exhaustive, but illustrative ${ }^{102}$. Accordingly, the concept of 'placement in institutional care' must be interpreted as covering placement in a secure care institution, provided that such placement is ordered to protect the child, and not to punish him or her ${ }^{103}$. 'Any other interpretation', the ECJ wrote, 'would mean that the benefit of the Regulation would be lost to the particularly vulnerable children who need such a placement and would be contrary to the purpose of the Regulation, set out in recital 5 , to ensure equality for all children.' ${ }^{104}$

100 The choice of that institution seems to have been determined by the fact that S.C. continually expressed the wish to be close to her mother, who resides in England, and by the fact that no other alternative placement could better meet S.C's specific needs.

101 Case C-92/12 PPU Health Service Executive, Judgment of 26 April 2012, not yet reported, para. 60, (referring to Case C-435/06 C [2007] ECR I-10141, para. 51).

102 Case C-435/06 C [2007] ECR I 10141, para. 30.

103 See, in this regard, Article 1(3)(g) of the Brussels II bis Regulation, which excludes from the scope of that Regulation 'measures taken as a result of criminal offences committed by children'.

104 Case C-92/12 PPU Health Service Executive, Judgment of 26 April 2012, not yet reported, para. 64, 
Second, the High Court asked, in essence, whether a consent emanating from an institution, which admits children in return for payment may constitute the consent of a competent authority within the meaning of Article 56(2) of the Brussels II bis Regulation. If not, the question was whether, in a situation where the referring court took the steps to obtain the consent but did not manage to determine whether that consent did indeed emanate from the competent authority, a posteriori correction of such irregularity was possible. The ECJ began by noting that the term 'authority' contained in Article 56(2) of the Brussels II bis Regulation designates an authority governed by public law. Whilst it is true that Member States may have different conceptions of what is or is not within the scope of public law, the ECJ pointed out that '[a]n independent assessment of whether the proposed placement is appropriate constitutes an essential measure for the protection of the child, in particular if that placement involves deprivation of liberty'. This means that '[a]n institution which profits from the placement is not in a position to make an independent determination in that regard' ${ }^{105}$. Next, the ECJ found that 'where a court in a requesting Member State has ruled on placement in reliance on an apparent consent from the competent authority, but where the information concerning the consent procedure under Article 56 of the Regulation raises doubts as to whether the requirements of that article have been fully complied with, there should exist the possibility that that court can correct the situation a posteriori in order to ensure that the consent was validly granted' ${ }^{106}$.

Third, the High Court asked whether a judgment of a court of a Member State, ordering the compulsory placement of a child in a secure care institution situated in another Member State must, before it can be enforced in the requested Member State, be recognised and declared to be enforceable in that Member State. As to recognition, the ECJ held that a judgment such as that at issue in the main proceedings is entitled to recognition in the requested Member State, unless and until an order of non-recognition has been made in that State in accordance with the grounds for non-recognition of judgments relating to parental responsibility which are exhaustively listed in Article 23 of the Brussels II bis Regulation. As to the need for a declaration of enforceability ${ }^{107}$, the ECJ observed that the enforcement of a judgment such as that at issue in the main proceedings may entail the use of coercion, given that S.C. was, against her will, deprived of her liberty. For example, if she were to abscond from the secure care institution where she is placed, the assistance of the UK authorities would be required in order to take her back by force to that institution, for her own protection. Accordingly, 'in order to ensure that the system intended by the Regulation operates properly, the use of coercion

105 Ibid.

106 Ibid., para. 92.

107 Article 28 of the Brussels II bis Regulation, entitled 'Enforceable judgments', reads as follows:

' 1 . A judgment on the exercise of parental responsibility in respect of a child given in a Member State which is enforceable in that Member State and has been served shall be enforced in another Member State when, on the application of any interested party, it has been declared enforceable there.

2. However, in the United Kingdom, such a judgment shall be enforced in England and Wales, in Scotland or in Northern Ireland only when, on the application of any interested party, it has been registered for enforcement in that part of the United Kingdom'. 
against a child in order to implement a judgment of a court of a Member State ordering her placement in a secure care institution in another Member State presupposes that the judgment has been declared to be enforceable in the latter State.' ${ }^{108}$

'[C]ircumstances associated with particular urgency cannot, by themselves, lead to the possibility that enforcement measures can be taken in another Member State on the basis of a decision ordering placement in secure institutional care which has not yet been recognised as being enforceable. ${ }^{109}$ That being said, the ECJ strived to find the options that are available by the Regulation, so that effective solutions can be found in the event that a cross-border placement has to be particularly expeditious. In light of Article 31(1) of the Brussels II bis Regulation, the court applied to for a declaration of enforceability is to give its decision without delay. However, Article 33 provides that the decision on the application for a declaration of enforceability may be appealed by either party within the period of one month from the date of service of that declaration ${ }^{110}$. Accordingly, in order not to undermine the effectiveness of the obligation laid down in Article 31(1), the ECJ ruled that such appeals may not produce suspensive effects: 'a placement order is to become enforceable at the point in time when the court of the requested Member State declares, in accordance with Article 31, that that order is enforceable'111. In addition, in light of Article 20(1) of the Regulation, the authorities of the requested Member State may adopt provisional measures which cease to apply when the court of the Member State having jurisdiction as to the substance of the matter has taken the measures it considers appropriate, i.e. until the conclusion of the procedure for obtaining a declaration of enforceability of the placement order $^{12}$.

Last, but not least, the referring court asked whether, whenever a court of a Member State which has ordered the placement of a child in institutional care in another Member State for a specified period, under Article 56 of the Regulation, adopts a new decision aimed at extending the duration of the placement, it is on each occasion necessary to obtain the consent of the competent authority in the requested Member State referred to in Article 56(2) of the Regulation and a declaration of enforceability under Article 28 of the Regulation. The ECJ held that a court of a Member State can give a judgment ordering the placement of a child in a care institution situated in another Member State only if the competent authority in the requested Member State has first consented to that placement. It follows that, where the competent authority of the requested Member State has given its consent to a placement by the court having jurisdiction which is limited in time, that placement cannot be extended unless that authority has given a further consent ${ }^{113}$.

108 Case C-92/12 PPU Health Service Executive, Judgment of 26 April 2012, not yet reported, para. 113.

109 Ibid., not yet reported, para. 119.

110 However, where the party, against whom enforcement is sought, is habitually resident in a Member State other than that, in which the declaration of enforceability was given, that period is to be extended to two months and is to run from the date when service is effected.

111 Case C-92/12 PPU Health Service Executive, Judgment of 26 April 2012, para.125, not yet reported.

112 Ibid., para. 131.

$113 \mathrm{Ibid}$., para. 138. However, if necessary, the court ordering the placement has the option of contemplating 


\section{Concluding remarks}

The principle of mutual trust is the cornerstone of the Brussels II bis Regulation. In accordance with that principle, every court of a Member State offers an equivalent and effective level of judicial protection. For child abduction cases, the Brussels II bis Regulation provides that the court of the Member State where the child is present may not review whether the proceedings carried out by the court of the Member State where that child was habitually resident immediately before the wrongful removal or retention are in violation of fundamental rights as protected by EU law. Otherwise, if the former court were allowed to second-guess the procedural and substantive determinations of the latter court, the strengthening of the summary return mechanism of the 1980 Hague Convention which the Brussels II bis Regulation pursues would not be possible. The principle of 'mutual trust' does not amount to a reduction in the level of fundamental rights protection. As the ECJ has consistently held, the Brussels II bis Regulation entrusts the courts of the Member State where the child was habitually resident immediately before the wrongful removal or retention with the judicial protection of the fundamental rights of the child concerned. Notwithstanding the adoption of provisional measures, it is thus for those courts to determine the measures which are necessary to protect the best interests of the child.

In addition, when interpreting the provisions of the Brussels II bis Regulation relating to matters of parental responsibility, the ECJ always takes into account the best interests of the child. For example, in $A$ and Mercredi, the ECJ favoured a flexible concept of 'habitual residence', since the best interests of the child require a detailed examination of all the relevant circumstances of the case at hand. Just like the authors of the 1980 Hague Convention, the EU legislator considered, when drafting the Brussels II bis Regulation, that child abduction is detrimental to the fundamental rights of the child. Accordingly, paying due deference to that policy choice, the ECJ in its interpretation of the Brussels II bis Regulation turned the latter into a powerful tool deterring wrongful removals and retentions. As Rinau, Povse and Aguirre Zarraga demonstrate, the Brussels II bis Regulation cannot be interpreted in a way that favours the parent responsible for the wrongful removal or retention. Likewise, Detiček shows that provisional measures adopted in accordance with Article 20 thereof cannot operate as means of circumventing the conflict-of-jurisdiction rules that apply in the event of the wrongful removal or retention. It is true that, as recognised by the ECJ itself in Detiček, the best interests of the child may advise in favour of not ordering his or her return to the Member State of origin ${ }^{114}$. However, contrary to the system set out in the 1980 Hague Convention, it is not for the court of the Member State of enforcement but for the court of the Member State of origin to take a final decision in this respect.

a placement order for a suitable period of time, in order to eliminate the disadvantages, associated with a series of declarations of enforceability of short duration, and of examining, at closely spaced intervals, whether it is appropriate, within the period covered by the declaration of enforceability, to review the placement order. Ibid., para. 145.

114 Case C-403/09, Detiček, [2009] ECR I-12143, para. 59. 
Seen in this light, the two objectives pursued by the Brussels II bis Regulation, namely, protecting the best interests of the child and enhancing mutual trust among national courts, are not in competition, but in a mutually depending relationship. The system set up by the Brussels II bis Regulation will work at its best where the court of the Member State of origin does its work properly, i.e. where it affords an effective judicial protection to the fundamental rights of the child concerned.

\section{References}

Balbontin v. United Kingdom, 14 September 1999, No 39067/97.

Barnard, C. The PPU: Is It Worth the Candle? An Early Assessment. European Law Review. 2009, 34.

Bosphorus Hava Yollarl Turizm ve Ticaret Anonim Şirketi v. Ireland [GC], Judgment of 30 June 2005, No. 45036/98, ECHR 2005VI.

Case C-101/01 Lindqvist [2003] ECR I-12971.

Case C-168/08 Hadadi [2009] ECR I-6871.

Case C-195/08 PPU Rinau [2008] ECR I-5271.

Case C-211/10 PPU Povse [2010] ECR I-6673.

Case C-256/09 Purrucker I [2010] ECR I-7353.

Case C-296/10 Purrucker II [2010] ECR I-11163.

Case C-305/05 Ordre des barreaux francophones et germanophone and Others [2007] ECR I-5305.

Case C-400/10 PPU McB [2010] ECR I-8965.

Case C-403/09 PPU Detiček [2009] ECR I-12193.

Case C-491/10 PPU Aguirre Zarraga [2010] ECR I-14247.

Case C-497/10 PPU Mercredi [2010] ECR I-14309.

Case C-523/07 $A$ [2009] ECR I-2805.

Case C-68/07 Sundelind Lopez [2007] ECR I-10403.

Case C-92/12 PPU Health Executive Security, Judgment of 26 April 2012, not yet reported. Chevalier, B. Les nouveaux développements de la procédure préjudicielle dans le domaine de l'espace judiciaire européen: la procédure préjudicielle d'urgence et les réformes principales prévues par le traité de Lisbonne. ERA Forum. 2009, 8.

Council Regulation (EC) No 1347/2000 of 29 May 2000 on jurisdiction and the recognition and enforcement of judgments in matrimonial matters and in matters of parental responsibility for children of both spouses, OJ [2000] L 160/19.

Council Regulation (EC) No 2201/2003 of 27 November 2003 concerning jurisdiction and the recognition and enforcement of judgments in matrimonial matters and the matters of parental responsibility, repealing Regulation (EC) No 1347/2000, OJ [2003] L 338/1.

Guichard v France, ECHR 2003-X 714.

Karoussiotis $v$ Portugal, Judgment of 1 February 2011, No. 23205/08.

Kuipers, J.-J. The (non) Application of the Charter of Fundamental Rights to a Certificate for the Return of a Child. European Human Rights Law Review. 2012, 4.

Lamont, R. Case Note on A. Common Market Law Review. 2010, 47.

Lenaerts, K. The Contribution of the European Court of Justice to the Area of Freedom, Security and Justice. International \& Comparative Law Quarterly. 2010, 59.

Mitsilegas, V. The Limits of Mutual Trust in Europe's Area of Freedom, Security and Justice: From Automatic Inter-State Cooperation to the Slow Emergence of the 
Individual. Yearbook of European Law. 2012, 31.

Naômé, C. La procédure accélérée et la procédure préjudicielle d'urgence devant la Cour de justice des Communautés européennes. Journal de droit européen. 2009.

Neulinger and Shuruk v. Switzerland [GC], Judgment of 6 July 2010, No. 41615/07, ECHR 2010.

Ní Shúilleabháin, M. Cross-border Divorce Law: Brussels II bis. Oxford: OUP, 2011.

Povse v Austria, Decision of 18 June 2013, No. 3890/11.

Ripley, P. A Defence of the Established Approach to the Grave Risk Exception in the Hague Child Abduction Convention. Journal of Private International Law. 2008, 4.

Rosas, A. Justice in Haste, Justice Denied? The European Court of Justice and the Area of Freedom, Security and Justice. Cambridge Yearbook of European Legal Studies. 20082009, 11.
The 1980 Hague Convention on the Civil Aspects of International Child Abduction.

The European Convention of 20 May 1980 on Recognition and Enforcement of Decisions concerning Custody of Children and on Restoration of Custody of Children.

The Hague Convention of 1 June 1970 on the Recognition of Divorces and Legal Separations.

The Hague Convention of 5 October 1961 concerning the Powers of Authorities and the Law Applicable in respect of the Protection of Minors.

The Luxembourg Convention of 8 September 1967 on the Recognition of Decisions Relating to the Validity of Marriages.

Walker, L.; Beaumont, P. Shifting the Balance Achieved by the Abduction Convention: The Contrasting Approaches of the European Court of Human Rights and the European Court of Justice. Journal of Private International Law. 2011, 7.

\section{VAIKO INTERESŲ APSAUGA VISUOMET YRA SVARBIAUSIA: BRIUSELIO II REGLAMENTAS IR EUROPOS TEISINGUMO TEISMO PRAKTIKA}

\section{Koen Lenaerts}

Europos Sajungos Teisingumo Teismas, Liuksemburgas

Anotacija. Šiame straipsnyje analizuojama Europos Teisingumo Teismo praktika, susijusi su Briuselio II bis reglamentu del jurisdikcijos ir teismo sprendimu, susijusiu su santuoka ir tèvu pareigomis, pripažinimo ir vykdymo.

Reikšminiai žodžiai: Europos Sajunga, tarptautine privatinè teisè, jurisdikcijos taisykliu konfliktas, $1980 \mathrm{~m}$. Hagos konvencija dèl tarptautinio vaiku grobimo civiliniu aspektu, Tarybos reglamentas (EB) Nr. 2201/2003 (Briuselio II bis reglamentas), laisvas teismo sprendimu judejimas, teisinis tikrumas, geriausi vaiko interesai, Europos Sajungos pagrindiniu teisiu chartijos 24 straipsnis, Europos Teisingumo Teismas. 


\title{
THE BEST INTERESTS OF THE CHILD ALWAYS COME FIRST: THE BRUSSELS II BIS REGULATION AND THE EUROPEAN COURT OF JUSTICE
}

\author{
Koen Lenaerts \\ Court of Justice of the European Union, Luxembourg
}

Summary. The purpose of the present contribution is to explore how the European Court of Justice (the ECJ) - in dialogue with national courts - has interpreted the Brussels II bis Regulation concerning jurisdiction and the recognition and enforcement of judgments in matrimonial matters and the matters of parental responsibility. The present paper is divided into four parts. Part 1 looks at the concept of 'habitual residence' of the child concerned which is the conflict-of-jurisdiction principle on which the Brussels II bis Regulation is based. In this regard, it is argued that that principle has been construed by the ECJ in such a way as to take account of the best interests of the child. In Part 2, the case law relating to the provisions of the Brussels II bis Regulation on child abduction is studied in great detail. That study shows that the ECJ seeks to interpret the Brussels II bis Regulation in light of the best interests of the child. Part 3 is devoted to examining the way in which the ECJ has interpreted the concept of 'provisional measures' which enables national courts to derogate from the conflict-of-jurisdiction principle set out in the Brussels II bis Regulation. In Part 4, the fact that that Regulation calls upon national authorities to cooperate with each other is illustrated by a judgment of the ECJ relating to the cross-border placement of a child. Finally, a brief conclusion supports the contention that the ECJ does not give absolute priority to the mobility of judgments over the protection of fundamental rights. On the contrary, as the case law clearly reveals, the ECJ will never interpret the Brussels II bis Regulation against the best interests of the child'.

Keywords: European Union, Private International Law, conflict-of-jurisdiction rules, The 1980 Hague Convention on the Civil Aspects of International Child Abduction, Regulation (EC) No 2201/2003 (the Brussels II bis Regulation), free movement of judgments, legal certainty, the best interests of the child, Article 24 of the Charter of Fundamental Rights of the European Union, the European Court of Justice.

Koen Lenaerts, Europos Sajungos Teisingumo Teismo viceprezidentas, Liuveno universiteto profesorius. Mokslinių tyrimų kryptys: Europos Sajungos teisè.

Koen Lenaerts, Vice-President of the Court of Justice of the European Union; Professor of European Union Law, Leuven University. Research interests: European Union Law. 